\title{
The First Identification and Some Carcass Characteristics of the 7 Lumbar Vertebrae in Sheep in Turkey
}

\section{Omer Faruk Gungor ( $\sim$ gungorvet@gmail.com )}

Bolu Abant İzzet Baysal Üniversitesi: Bolu Abant Izzet Baysal Universitesi https://orcid.org/0000-0002-7273-7242

Necmettin Unal

Ankara Universitesi Veteriner Fakultesi

Ceyhan Ozbeyaz

Ankara Universitesi Veteriner Fakultesi

\section{Research Article}

Keywords: lamb, lumbar vertebrae number, slaughter traits, carcass traits

Posted Date: June 8th, 2021

DOI: https://doi.org/10.21203/rs.3.rs-569317/v1

License: (c) (i) This work is licensed under a Creative Commons Attribution 4.0 International License. Read Full License 


\section{Abstract}

The purpose of this study was to draw attention to the number of the lumbar vertebrae in $R_{1} B B A$ crosses (Bafra $x F_{1}$ (Bafra $x$ Akkaraman)) lambs (75\% Bafra and 25\% Akkaraman), and the effect of 7 lumbar vertebrae on some carcass traits. Even though some studies reported that the number of the lumbar vertebrae might be considerably different dependent on the sheep genotype, this has not been reported for Turkish breeds. While a study on the $\mathrm{R}_{1} \mathrm{BBA}$ lambs has been performed, seven lumbar vertebrae have been identified in four of the eighteen lambs. The means of the carcass length $(80.800 \pm 0.583$ and $84.375 \pm 1.375 \mathrm{~cm})(P=$ $0.036)$, leg weight $(5.942 \pm 0.079$ and $6.209 \pm 0.052 \mathrm{~kg})(P=0.032)$, loin weight $(1.560 \pm 0.096$ and $1.849 \pm 0.060 \mathrm{~kg})(P=0.048)$, and loin's lean weight $(0.875 \pm 0.059$ and $1.058 \pm 0.032 \mathrm{~kg})(P=0.040)$ were statistically different between the groups of lambs $(6$ and 7 lumbar vertebrae, respectively). In conclusion, the number of lumbar vertebrae has economically affected important parts of the carcass.

\section{Introduction}

The mammalian vertebral column, also known as the spinal column or spin, consists of a sequence and repeating bones called vertebrae and is divided into five morphologically different and functionally distinct spinal regions (cervical, thoracic, lumbar, sacral and caudal vertebrae) (Donaldson et al., 2013; Zhang et al., 2019). The vertebrae number of the each region gives the vertebral pattern, and this pattern is generally $\mathrm{C}_{7} \mathrm{~T}_{13} \mathrm{~L}_{6(7)} \mathrm{S}_{4} \mathrm{Ca}(\mathrm{Cy})_{16-18}$ in the sheep breeds (Akers e Denbow, 2013). This pattern varies across the mammalian species, but the cervical vertebrae number is conserved at a total of seven in the mammalian species except for a few species (Lee et al., 2011; Lambe et al., 2014). Moreover, the vertebral number of the post-cervical region shows differences between and within the breeds. For instance, Arabian horses have one less lumbar vertebrae than the all other common horse breeds, and European commercial pig breeds $(n=21-23)$ have more thoracolumbar vertebrae than the Asian breeds ( $n=19-20)$ (Borchers et al., 2004; Zhang et al., 2017; Reese, 2019). In the sheep, European breeds $(n=17-21)$ and Chinese indigenous breeds $(n=19-21)$ may reveal the range of variation in terms of the thoracolumbar vertebrae number (Zhang et al., 2017, 2019). It is reported that lumbar vertebrae numbers of the Texel, Scottish Blackface, and Mongolia sheep have shown a variation between 4 and 7; 6 and 8; 6 and 7, respectively (Zhang et al., 1998; Donaldson et al., 2013).

The length of the thoracolumbar region affects the production traits, so the variation of the thoracolumbar vertebra number within the breeds can be used to increase the production yields per animal. For example, Arabian horses have five lumbar vertebrae, and this trait provides them a better endurance ability than other horse breeds. On the other hand, long thoracolumbar region in the livestock affects the body length, carcass traits and the amount of quality meat in the carcass because this region is the most valuable section of the carcass. In addition, long body length can affect the fertility and milking traits since the long lumbar region provides larger area for genital organs (Akçapınar e Özbeyaz, 1999; Akçapınar, 2000).

It is known that vertebral number was highly heritable in the pigs (King e Roberts, 1960; Borchers et al., 2004), and the selection of pig broods with longer back trait caused more thoracolumbar vertebras in the commercial pig breeds having 21 to 23 thoracolumbar vertebras than their ancestors having 19 thoracolumbar vertebras (Fredeen e Newman, 1962; Yang et al., 2009; Donaldson et al., 2013). King and Roberts (1960) reported that each extra vertebrae caused an increase of about $1.5 \mathrm{~cm}$ in the carcass length, and on the other hand Tohara (1967) stated this variation in the pig breeds could cause totally $85 \mathrm{~mm}$ extension in the carcass length.

As already mentioned, the trochal and lumbar vertebrae numbers in the sheep show a variation between and within the breed. Higher thoracolumbar vertebrae number is a desirable trait; therefore, this is expected to increase in the sheep populations. Zhang and Siqin (1998) indicated this rate increase in the Mongolian sheep between 1982 and 1996 years. The heritability of the vertebra number in the sheep is different for separate vertebral regions. While this trait in the Texel sheep is high for the trochal region $\left(h^{2}=0.99 ; \mathrm{SE}=0.42\right)$, it is relatively low for the lumbar region $\left(h^{2}=0.08 ; \mathrm{SE}=0.12\right)($ Donaldson, 2015).

Genetic control of the vertebral morphology was determined to be done by the Hox gene family (Wellik, 2007). Previous studies showed that Vertin (VRTN) gene affects the thoracic vertebrae number in sheep and pigs, and NR6A1 gene affects the lumbar vertebrae number in pigs (Yang et al., 2016; Li et al., 2019).

Page 2/15 
The objective of this current study was to evaluate the effect of 6 and 7 lumbar vertebrae numbers (Fig. 1) on the slaughter and carcass traits in the $\mathrm{R}_{1}$ BBA genotype.

\section{Materials And Methods}

\section{Animals}

This study was performed using $9 \mathrm{R}_{1}$ BBA lambs (5 lambs having 6 lumbar vertebrae and 4 lambs having 7 lumbar vertebrae). $\mathrm{R}_{1}$ BBA lamb is a crossbreed genotype, obtained via the crossbreeding of Bafra (75\%) and Akkaraman (25\%) breeds at the Gozlu state farm ( $38^{\circ} 29^{\prime} \mathrm{N}$ and $32^{\circ} 27^{\prime} \mathrm{E}, 1020 \mathrm{~m}$ of altitude) in the central Anatolia region of Turkey. Bafra rams mated with Akkaraman ewes, and $F_{1}$ ewes were then backcrossed with Bafra rams to produce the second cross $\left(R_{1}\right)$ lambs.

Lambs were separated from dams at an average 90 days of age (weaning) and fattened during 84 days with ad-libitum concentrate fed (15\% crude protein and 2,800 kcal/ $\mathrm{kg} \mathrm{ME})$ and $300 \mathrm{~g}$ alfalfa hay per animal/day. Finally, lambs having 6 and 7 lumbar vertebrae were slaughtered at a mean weight of $42.950 \pm 0.877$ and $42.175 \pm 0.893 \mathrm{~kg}$, respectively.

\section{Slaughtering and Carcass characteristics}

Lambs' weights were determined 12 hours before slaughter, and then when fasting just before slaughter. Head, skin, feet, heart, lungs, liver, spleen, testicles, full digestive tract, empty rumen, empty intestine, trachea-esophagus, omental fat, and mesenteric fat were removed and weighted after bleeding. Then, the carcass measurements were taken.

The length of the carcass (between the caput humeri and tuber ischia), the back (between the distal cranial points of the shoulder and the tail), the leg internal (between the cranial edge of symphysis pubis and the tarsal-metatarsal joint), the leg external (between the articulatio coxae and the tarsal-metatarsal joint), the rump (between the tuber coxae and tuber ischia) and the neck (between the distal cranial point of the shoulder and cranial point of the neck) were measured on the carcasses. Similarly, the width of the leg (distance between the two gigots at the junction point alignment of the legs), the chest (distance between the left and right of the extremitas proximalis scapulas) and the rump (distance between the articulationes coxae) were obtained on the carcasses. Then, leg circumference (over the articulationes coxae on the carcass), chest girth (over the caudal points of the scapulas), rump girth (over the articulationes coxae), chest depth (distance between the sternum and the withers) were taken. Carcass compactness and leg compactness indexes were calculated by the formulae: cold carcass weight/length (kg/m) and leg weight/length $(\mathrm{kg} / \mathrm{m})$, respectively (Santos et al., 2007).

Gastrointestinal tracts were weighed both full and empty to identify gastro-intestinal contents weights, and empty body weight was calculated using these values. Consequently, dressing percentages were calculated based on slaughter weight and empty body weight. The carcass body (including perinephric-pelvic fat and kidneys) was chilled at $4^{\circ} \mathrm{C}$ for $24 \mathrm{~h}$ and weighed. To measure the eye muscle (MLD: musculus longissimus dorsi) area $\left(\mathrm{cm}^{2}\right)$, it was drawn onto the transparency sheet at the level of the 12th and 13th rib $24 \mathrm{~h}$ after the slaughter, and this figure area was calculated using the AutoCAD software (version 2019). At the same time, the fat depth was measured from subcutaneous fat using a caliper in this region.

After this period, tail, perinephric-pelvic fat and kidneys were separated from the carcasses, and the carcasses were symmetrically divided through the columna vertebralis. Left and right side of the carcass were weighed, and left side was cut into six sections (leg, foreleg, back, loin, neck and breast + flank) according to the Akçapınar (1981). These individual cuts were grouped by first quality (leg, back, and loin), second quality (foreleg), and third quality (neck and breast + flank) according to the Díaz et al. (2006). Each individual cut piece was dissected and weighed as the lean, bone, fat, and remainder.

\section{Statistical analysis}

In this study, SPSS software package (SPSS Software, 2005) was used for the one-way analysis of variance method to determine the influence of having 6 and 7 lumbar vertebrae lambs within the genotype on the slaughter and carcass characteristics. 


\section{Results}

\section{Slaughter characteristics}

The values of the slaughter characteristics were presented in Table 1. The differences in the slaughter characteristics between L6 and L7 lamb groups were not significant. This result can be considered to be normal since the final and slaughter weights of two groups are very close.

There were not any significant differences between the non-carcass components of two groups (Table 2). It, however, draws attention to the weight of skin, head, and omental fat which are higher for the lambs having 6 lumbar vertebrae.

The traits of carcass measurements were shown in Table 3. As expected, carcass length of the lambs having 7 lumbar vertebrae was significantly $(P=0.036)$ longer than the lambs having 6 lumbar vertebrae. There were no significant differences between two groups for other values except for rump width $(P=0.048)$. Besides, leg external length and neck length were numerically better for the lambs having 7 vertebrae.

\section{Carcass characteristics}

The means, minimum-maximum values and ratios for individual cuts and compositions of carcasses were given in Table 4. Except for weight of leg $(P=0.032)$ and loin $(P=0.048)$, all values between two genotypes were found to be statistically unimportant. The highest leg and loin weights were obtained for the lambs having 7 lumbar vertebrae (Fig. 2).

Eye muscle area, back fat depth, lean/bone and lean/fat values were reported in Fig. 3. There were no statistical differences between two groups in terms of these values. Eye muscle area and lean/ fat values of the lambs having 7 lumbar vertebrae, however, are larger than those of the lambs having 6 lumbar vertebrae. In addition, the back fat depth of the lambs having 7 lumbar vertebrae was lower than that of the lambs having 6 lumbar vertebrae.

Table 5 illustrated the results measured and calculated for the composition of the individual cuts in the carcass. As expected, the lean weight in the loin cuts of the group having 7 lumbar vertebrae was significantly $(P=0.040)$ higher than that of the other group having 6 lumbar vertebrae (Fig. 4).

\section{Discussion}

Generally, lamb meat production is the primary function of the world and Turkey sheep industry. The profit increase in this industry can be achieved in a number of ways; and especially development of the carcass quality traits is one of those ways. The detection of the easy identification methods, determination of the gene effects on the carcass characteristics and using those in the animal breeding programs can provide an increase in the amount of muscle and saleable meat for specific body regions or cuts. For instance, the increase in the trochal and/or lumbar vertebrae numbers (i.e. larger carcass length and lumbar vertebrae number) is significant in terms of sheep meat production.

As a result of this information, it is known that larger lumbar vertebrae number will affect the quality meat ratio in the carcass. Therefore, the evaluation of the vertebral number in the sheep breed can improve the profit of the producer per animal.

Comparison of lumbar vertebrae numbers of $\mathrm{R}_{1} \mathrm{BBA}$ genotype showed that the lambs having 7 lumbar vertebrae had better quality meat ratio because of the leg and loin weights, lean value in the loin section, and long carcass length (Tables $1,3,4$, and Figs. 2 and 4).

The leg and loin weights and lean meat content in the loin were significantly affected from lumbar vertebrae number. It is clear that these results will affect the quality meat ratio in the lamb carcass, and these desirable traits are commercially valuable because of their sale at higher prices. The similar studies in the pig breeds were performed with the variation of vertebral numbers, and their outcome on the carcass traits. The results of those also revealed that the increasing in the lumbar vertebrae numbers affect the quality meat ratio in carcass (Tohara, 1967; Borchers et al., 2004).

Page $4 / 15$ 
The back length mean of the lambs having 7 lumbar vertebrae was $2.275 \mathrm{~cm}$ longer than that of the lambs having 6 lumbar vertebrae. It can be inferred from this result that one extra lumbar vertebra causes $2.275 \mathrm{~cm}$ in length. This finding is similar with Li et al.'s (2017) (lumbar vertebrae length $=2.22 \mathrm{~cm}$ ) and Zhang et al.'s (2017) (lumbar vertebrae length $=1.30 \mathrm{~cm}$ ) in China, and Donaldson's (2015) results (lumbar vertebrae length $=2.91 \mathrm{~cm}$ ) in the United Kingdom. In addition to those, same condition was reported in the pig breeds (King e Roberts, 1960; Tohara, 1967).

The back fat depth of the lambs having 7 lumbar vertebrae group was lower than that of the lambs having 6 lumbar vertebrae groups, which was in accordance with total fat value in the carcass. Therewithal, these findings were also consistent with Borchers et al.'s (2004) results in the pig. The back fat depth and rump width values of the lambs having 6 lumbar vertebrae were higher than those of another group. In addition, the lambs having 6 lumbar vertebrae have higher skin and omental fat weight than the lambs having 7 lumbar vertebrae. When these data were assessed, it can be said that the lambs having 7 lumbar vertebrae were still developing stage than the lambs having 6 lumbar vertebrae in this slaughter weight. Some researchers reported that the piglets having 7 lumbar vertebrae had a tendency toward a higher age at slaughter (Meyer e Lindfeld, 1969).

The eye muscle area in the 7 lumbar vertebrae group had larger than another group. Although this difference was not very vital, the value was close to the significance level $(P=0.091)$. This result was in accordance with Borchers et al.'s (2004) findings at which they reported that more lumbar vertebrae in pigs were significantly affected by the eye muscle area value. In addition, eye muscle area is a significant indicator of lean meat quantity and body muscling (especially hind-leg muscles) in the sheep (Hopkins et al., 1992; Cloete et al., 2004). In this study, it was identified that the lambs with 7 lumbar vertebrae have a larger eye muscle area with a heavier leg and loin, and also higher lean weight in the leg and loin than the lambs with 6 lumbar vertebrae. These results were correlated with other studies with these aspects (Hopkins et al., 1992; Cloete et al., 2004).

It was concluded that the lambs having 7 lumbar vertebrae had significantly higher carcass length, leg weight, loin weights and loin's lean weight. The evaluation of the vertebral number and using this information in the animal breeding programs will affect the profit per sheep in the world. As a result of this work, we can say that identification of the variation of the vertebrae number for Turkey sheep breeds by the ultrasound or genetic testing can be used as the selection criteria for the sheep breeding.

\section{Declarations}

\section{Acknowledgments}

The authors gratefully acknowledge the contribution of esteemed senior Prof Dr. Halil Akcapinar, who was retired from Ankara University.

\section{Contributions}

OF Gungor, C Ozbeyaz and N Unal conceived and designed research. OF Gungor and N Unal conducted experiments. OF Gungor analyzed the data and wrote the manuscript. C Ozbeyaz and N Unal reviewed and supervised, and C Ozbeyaz edited the manuscript. All authors read and approved the manuscript.

Funding information This project was supported by Ankara University Scientific Research Projects Coordination Unit (64299502604.01.02-E.84290).

Data availability The datasets generated during and/or analysed during the current study are available from the corresponding author on reasonable request.

\section{Compliance with ethical standards}

Conflict of interest The authors declare no conflict of interest.

Ethical standards All animal procedures were conducted under the protocol approved by the Ankara University Animal Experiments Local Ethics Committee (File no. 2018-34, Decision no. 2018-4-36). 


\section{References}

1. Akçapınar, H., 1981. Dağlıç, Akkaraman ve Kıvırcık kuzuların entansif beside büyüme ve yemden yararlanma kabiliyeti üzerinde karşılaştırmalı araştırmalar4. Veterinary Journal of Ankara University, 28 (1-4), 112-129

2. Akçapınar, H., 2000. Koyun Yetiştiriciliği, $2^{\circ}$ ed. (İsmat Matbaacılık: Ankara)

3. Akçapınar, H. e Özbeyaz, C., 1999. Hayvan Yetiştiriciliği Temel Bilgileri, (Kariyer Matbaacılık)

4. Akers, R. e Denbow, D., 2013. Bones and skeletal system In:, Anatomy and Physiology of Domestic Animals, (John Wiley \& Sons, Incorporated, Hoboken), 155

5. Borchers, N., Reinsch, N. e Kalm, E., 2004. The number of ribs and vertebrae in a Piétrain cross: Variation, heritability and effects on performance traits Journal of Animal Breeding and Genetics, 121, 392-403

6. Cloete, J.J.E., Cloete, S.W.P., Hoffman, L.C. e Fourie, J.E., 2004. Slaughter traits of Merino sheep divergently selected for multiple rearing ability South African Journal of Animal Sciences, 34, 189-196

7. Díaz, M.T., Fuente, J. de la, Pérez, C., Lauzurica, S., Álvarez, I., Huidobro, F.R. de, Velasco, S. e Cañeque, V., 2006. Body composition in relation to slaughter weight and gender in suckling lambs Small Ruminant Research, 64

8. Donaldson, C.L., 2015. Spine characteristics in sheep: Metrology, relationship to meat yield, and their genetic parameters (University of Edinburg)

9. Donaldson, C.L., Lambe, N.R., Maltin, C.A., Knott, S. e Bunger, L., 2013. Between- and Within-Breed Variations of Spine Characteristics in Sheep Journal of Animal Science, 91, 995-1004

10. Fredeen, H.T. e Newman, J.A., 1962. RIB AND VERTEBRAL NUMBERS IN SWINE.: I. VARIATION OBSERVED IN A LARGE POPULATION Canadian Journal of Animal Science, 42, 232-239

11. Hopkins, D.L., Gilbert, K.D., Pirlot, K.L. e Roberts, A.H.K., 1992. Elliotdale and crossbred lambs: Growth rate, wool production, fat depth, saleable meat yield, carcass composition and muscle content of selected cuts Australian Journal of Experimental Agriculture, 32

12. King, J.W.B. e Roberts, R.C., 1960. CARCASS LENGTH IN THE BACON PIG; ITS ASSOCIATION WITH VERTEBRAE NUMBERS AND PREDICTION FROM RADIO- GRAPHS OF THE YOUNG PIG A.R.C. Animal Breeding Research Organisation, Edinburgh, 9 , $59-65$

13. Lambe, N.R., Donaldson, C.L., Mclean, K.A., Gordon, J., Menezes, A.M., Clelland, N. e Bünger, L., 2014. Genetic control of CTbased spine traits in elite Texel rams 52-55

14. Lee, Y.J., Mcpherron, A., Choe, S., Sakai, Y., Roshantha, A., Lee, S. e Oh, S.P., 2011. Growth differentiation factor 11 signaling controls retinoic acid activity for axial vertebral development 347, 195-203

15. Li, C., Li, M., Li, X., Ni, W., Xu, Y., Yao, R., Wei, B., Zhang, M., Li, H., Zhao, Y., Liu, L., Ullah, Y., Jiang, Y. e Hu, S., 2019. WholeGenome Resequencing Reveals Loci Associated With Thoracic Vertebrae Number in Sheep Frontiers in Genetics, 10, 1-8

16. Li, C., Zhang, X., Cao, Y., Wei, J., You, S., Jiang, Y., Cai, K., Wumaier, W., Guo, D., Qi, J., Chen, C., Ni, W. e Hu, S., 2017. Multivertebrae variation potentially contribute to carcass length and weight of Kazakh sheep Small Ruminant Research, 150, 810 (Elsevier B.V.)

17. Meyer, H. e Lindfeld, A., 1969. Untersuchungen über Wirbelzahl und Wirbellänge beim Deutschen veredelten Landschwein. Deutsche tierarztliche Wochenschrift, 76, 448-453

18. Reese, H.H., 2019. Arabian horse breeding, (Pickle Partners Publishing)

19. Santos, V.A.C., Silva, S.R., Mena, E.G. e Azevedo, J.M.T., 2007. Live weight and sex effects on carcass and meat quality of «Borrego terrincho-PDO» suckling lambs Meat Science, doi: 10.1016/j.meatsci.2007.05.019

20. SPSS Software, V. 14. 0., 2005. Statistical Package for Social Sciences for window, Statistical Innovations Inc. (Versiyon 14.01; No: 9869264). USA (Statistical Innovations Inc: USA)

21. Tohara, S., 1967. Pig Improvement with Special Reference to the Number of Vettebrae -Variation of the Number of Vertebrae in Pigs- japan Agricultural Research Quarterly, 2, 29-34

22. Wellik, D.M., 2007. Hox patterning of the vertebrate axial skeleton Developmental Dynamics, 236, 2454-2463 
23. Yang, G., Ren, J., Zhang, Z. e Huang, L., 2009. Genetic evidence for the introgression of Western NR6A1 haplotype into Chinese Licha breed associated with increased vertebral number Animal Genetics, 40, 247-250

24. Yang, J., Huang, L., Yang, M., Fan, Y., Li, L., Fang, S., Deng, W., Cui, L., Zhang, Z., Ai, H., Wu, Z., Gao, J. e Ren, J., 2016. Possible introgression of the VRTN mutation increasing vertebral number, carcass length and teat number from Chinese pigs into European pigs Scientific Reports, 6, 1-8 (Nature Publishing Group)

25. Zhang, L., Luo, X. e Siqinbilig, S., 1998. The lengths of thoracic and lumbar vertebrae and the performance of Mongolia sheep Journal of Inner Mongolia Institute of Agriculture and Animal Husbandry, 19(3), 1-5

26. Zhang, L. e Siqin, B., 1998. The Genetic Patterns and the Performance Testing of Multivertebrae Mongolia Sheep (China)

27. Zhang, X., Li, C., Li, X., Liu, Z., Ni, W., Cao, Y., Yao, Y., Islamov, E., Wei, J., Hou, X. e Hu, S., 2019. Association analysis of polymorphism in the NR6A1 gene with the lumbar vertebrae number traits in sheep Genes and Genomics, 41, 1165-1171 (Springer Singapore)

28. Zhang, Z., Sun, Y., Du, W., He, S., Liu, M. e Tian, C., 2017. Effects of vertebral number variations on carcass traits and genotyping of Vertnin candidate gene in Kazakh sheep Asian-Australasian Journal of Animal Sciences, 30, 1234-1238

\section{Tables}

Table 1 Means $( \pm$ SE) of slaughter characteristics

\begin{tabular}{|llllll|}
\hline Trait & Means & & & Minimum & Maximum \\
& $\mathrm{L6}(\mathrm{n}: 5)$ & $\mathrm{L7}(\mathrm{n}: 4)$ & Sig. & L6 - L7 & L6 - L7 \\
\hline Final weight $(\mathrm{kg})$ & $44.020 \pm 0.905$ & $44.088 \pm 0.915$ & 0.960 & $42.450-42.750$ & $46.700-46.750$ \\
\hline Slaughter weight $(\mathrm{kg})$ & $42.950 \pm 0.877$ & $42.175 \pm 0.893$ & 0.560 & $41.350-41.200$ & $45.450-44.850$ \\
\hline Empty body weight $(\mathrm{kg})$ & $40.663 \pm 0.755$ & $40.636 \pm 0.861$ & 0.981 & $39.179-39.197$ & $43.042-43.071$ \\
\hline Hot carcass weight $(\mathrm{kg})$ & $20.452 \pm 0.590$ & $20.211 \pm 0.529$ & 0.776 & $18.982-19.395$ & $22.589-21.766$ \\
\hline Carcass weight $(\mathrm{kg})$ & $19.720 \pm 0.524$ & $19.650 \pm 0.403$ & 0.922 & $18.400-19.000$ & $21.600-21.800$ \\
\hline Hot dressing ${ }^{\mathrm{a}}(\%)$ & $47.627 \pm 1.062$ & $47.909 \pm 0.304$ & 0.826 & $44.853-47.075$ & $50.535-48.531$ \\
\hline Hot dressing ${ }^{\mathrm{b}}(\%)$ & $50.270 \pm 0.738$ & $49.730 \pm 0.531$ & 0.591 & $48.449-48.763$ & $52.481-50.756$ \\
\hline Chilled dressing ${ }^{\mathrm{a}}(\%)$ & $45.940 \pm 1.081$ & $46.960 \pm 0.312$ & 0.617 & $42.684-46.116$ & $48.322-47.515$ \\
\hline Chilled dressing ${ }^{\mathrm{b}}(\%)$ & $48.485 \pm 0.724$ & $48.360 \pm 0.231$ & 0.890 & $46.455-47.868$ & $50.183-48.983$ \\
\hline
\end{tabular}

L6 and L7: No. of lumbar vertebrae

a Based-on slaughter weight

${ }^{b}$ Based on empty body weight

Table 2 Means $( \pm S E)$, minimum-maximum values and ratios $( \pm S E)$ for non-carcass components 


\begin{tabular}{|c|c|c|c|c|c|c|c|c|}
\hline \multirow[t]{2}{*}{ Trait } & \multicolumn{3}{|l|}{ Means $(\mathrm{kg})$} & \multirow{2}{*}{$\begin{array}{l}\text { Minimum } \\
\text { L6 - L7 }\end{array}$} & \multirow{2}{*}{$\begin{array}{l}\text { Maximum } \\
\text { L6 - L7 }\end{array}$} & \multicolumn{3}{|c|}{ Ratio (as \% of slaughter weight) } \\
\hline & L6 (n:5) & L7 (n:4) & Sig. & & & L6 & L7 & Sig. \\
\hline Skin & $5.785 \pm 0.401$ & $5.043 \pm 0.289$ & 0.197 & $\begin{array}{l}4.650- \\
4.476\end{array}$ & $\begin{array}{l}7.017- \\
5.820\end{array}$ & $13.428 \pm 0.722$ & $11.935 \pm 0.466$ & 0.147 \\
\hline Head & $2.201 \pm 0.031$ & $2.098 \pm 0.072$ & 0.199 & $\begin{array}{l}2.143- \\
1.881\end{array}$ & $\begin{array}{l}2.316- \\
2.185\end{array}$ & $5.132 \pm 0.068$ & $4.980 \pm 0.173$ & 0.401 \\
\hline Feet & $0.978 \pm 0.035$ & $0.990 \pm 0.035$ & 0.822 & $\begin{array}{l}0.875- \\
0.886\end{array}$ & $\begin{array}{l}1.079- \\
1.041\end{array}$ & $2.286 \pm 0.111$ & $2.348 \pm 0.074$ & 0.678 \\
\hline Heart & $0.175 \pm 0.007$ & $0.184 \pm 0.005$ & 0.322 & $\begin{array}{l}0.159- \\
0.169\end{array}$ & $\begin{array}{l}0.191- \\
0.192\end{array}$ & $0.410 \pm 0.023$ & $0.438 \pm 0.011$ & 0.353 \\
\hline Lungs & $0.723 \pm 0.040$ & $0.640 \pm 0.034$ & 0.170 & $\begin{array}{l}0.617- \\
0.588\end{array}$ & $\begin{array}{l}0.819- \\
0.734\end{array}$ & $1.680 \pm 0.071$ & $1.523 \pm 0.097$ & 0.222 \\
\hline Liver & $0.937 \pm 0.033$ & $0.951 \pm 0.041$ & 0.787 & $\begin{array}{l}0.831- \\
0.899\end{array}$ & $\begin{array}{l}1.029- \\
1.074\end{array}$ & $2.180 \pm 0.064$ & $2.250 \pm 0.049$ & 0.433 \\
\hline Kidneys & $0.148 \pm 0.007$ & $0.146 \pm 0.004$ & 0.844 & $\begin{array}{l}0.135- \\
0.140\end{array}$ & $\begin{array}{l}0.175- \\
0.155\end{array}$ & $0.346 \pm 0.021$ & $0.3475 \pm 0.005$ & 0.953 \\
\hline Spleen & $0.117 \pm 0.018$ & $0.103 \pm 0.013$ & 0.571 & $\begin{array}{l}0.073- \\
0.078\end{array}$ & $\begin{array}{l}0.180- \\
0.139\end{array}$ & $0.274 \pm 0.044$ & $0.245 \pm 0.033$ & 0.631 \\
\hline Testicles & $0.308 \pm 0.015$ & $0.317 \pm 0.004$ & 0.609 & $\begin{array}{l}0.270- \\
0.309\end{array}$ & $\begin{array}{l}0.360- \\
0.325\end{array}$ & $0.716 \pm 0.023$ & $0.755 \pm 0.014$ & 0.223 \\
\hline $\begin{array}{l}\text { Trachea- } \\
\text { Esophagus }\end{array}$ & $0.094 \pm 0.009$ & $0.092 \pm 0.006$ & 0.816 & $\begin{array}{l}0.074- \\
0.077\end{array}$ & $\begin{array}{l}0.124- \\
0.106\end{array}$ & $0.220 \pm 0.017$ & $0.220 \pm 0.020$ & 1.000 \\
\hline $\begin{array}{l}\text { Full digestive } \\
\text { tract }\end{array}$ & $7.329 \pm 0.451$ & $7.367 \pm 0.293$ & 0.949 & $\begin{array}{l}6.334- \\
6.692\end{array}$ & $\begin{array}{l}8.918- \\
7.992\end{array}$ & $17.048 \pm 0.884$ & $17.458 \pm 0.499$ & 0.719 \\
\hline Empty rumen & $1.250 \pm 0.044$ & $1.226 \pm 0.073$ & 0.779 & $\begin{array}{l}1.160- \\
1.118\end{array}$ & $\begin{array}{l}1.405- \\
1.439\end{array}$ & $2.912 \pm 0.090$ & $2.915 \pm 0.190$ & 0.988 \\
\hline $\begin{array}{l}\text { Empty } \\
\text { intestine }\end{array}$ & $1.713 \pm 0.032$ & $1.835 \pm 0.081$ & 0.174 & $\begin{array}{l}1.645- \\
1.653\end{array}$ & $\begin{array}{l}1.833- \\
2.018\end{array}$ & $4.000 \pm 0.142$ & $4.348 \pm 0.145$ & 0.134 \\
\hline Omental fat & $0.548 \pm 0.056$ & $0.431 \pm 0.067$ & 0.217 & $\begin{array}{l}0.429- \\
0.309\end{array}$ & $\begin{array}{l}0.686- \\
0.585\end{array}$ & $1.276 \pm 0.131$ & $1.018 \pm 0.141$ & 0.224 \\
\hline $\begin{array}{l}\text { Mesenteric } \\
\text { fat }\end{array}$ & $0.461 \pm 0.033$ & $0.423 \pm 0.052$ & 0.536 & $\begin{array}{l}0.330- \\
0.273\end{array}$ & $\begin{array}{l}0.510- \\
0.510\end{array}$ & $1.074 \pm 0.073$ & $0.998 \pm 0.114$ & 0.575 \\
\hline
\end{tabular}

L6 and L7: No. of lumbar vertebrae

Table 3 Means $( \pm S E)$ and minimum-maximum values for carcass measurements 


\begin{tabular}{|llllll|}
\hline Trait & \multicolumn{2}{l}{ Means $(\mathrm{cm})$} & & Minimum & Maximum \\
\cline { 2 - 6 } & $\mathrm{L6}(\mathrm{n}: 5)$ & $\mathrm{L} 7(\mathrm{n}: 4)$ & Sig. & L6 - L7 & L6 - L7 \\
\hline Carcass length & $80.800 \pm 0.583$ & $84.375 \pm 1.375$ & 0.036 & $79.000-80.500$ & $82.000-87.000$ \\
\hline Back length & $61.600 \pm 1.208$ & $63.875 \pm 0.747$ & 0.178 & $57.000-62.000$ & $64.000-65.500$ \\
\hline Leg internal length & $28.000 \pm 0.652$ & $27.375 \pm 0.747$ & 0.547 & $26.500-26.000$ & $30.000-29.500$ \\
\hline Leg external length & $41.000 \pm 0.474$ & $42.000 \pm 0.677$ & 0.252 & $39.500-41.000$ & $42.000-44.000$ \\
\hline Rump length & $7.400 \pm 0.510$ & $7.625 \pm 0.554$ & 0.775 & $6.000-6.500$ & $9.000-9.000$ \\
\hline Neck length & $14.700 \pm 0.700$ & $15.750 \pm 0.433$ & 0.272 & $13.000-14.500$ & $17.000-16.500$ \\
\hline Leg circumference & $48.900 \pm 0.510$ & $48.875 \pm 0.657$ & 0.976 & $47.500-47.000$ & $50.000-50.000$ \\
\hline Chest girth & $75.800 \pm 0.735$ & $75.750 \pm 1.250$ & 0.972 & $74.000-73.000$ & $78.000-79.000$ \\
\hline Rump girth & $58.900 \pm 1.308$ & $58.625 \pm 0.800$ & 0.872 & $54.500-57.000$ & $62.000-60.000$ \\
\hline Leg width & $16.900 \pm 0.245$ & $16.750 \pm 0.323$ & 0.717 & $16.000-16.000$ & $17.500-17.500$ \\
\hline Chest width & $17.900 \pm 0.332$ & $17.250 \pm 0.433$ & 0.264 & $17.000-16.000$ & $19.000-18.000$ \\
\hline Rump width & $17.700 \pm 0.122$ & $17.250 \pm 0.144$ & 0.048 & $17.500-17.000$ & $18.000-17.500$ \\
\hline Chest depth & $27.700 \pm 0.300$ & $28.625 \pm 0.625$ & 0.195 & $27.000-27.000$ & $28.500-30.000$ \\
\hline
\end{tabular}

L6 and L7: No. of lumbar vertebrae

Table 4 Means $( \pm S E)$, minimum-maximum values and ratios $( \pm S E)$ for individual cuts and composition of carcasses 


\begin{tabular}{|c|c|c|c|c|c|c|c|c|}
\hline \multirow[t]{2}{*}{ Trait } & \multicolumn{3}{|l|}{ Means $(\mathrm{kg})$} & \multirow{2}{*}{$\begin{array}{l}\text { Minimum } \\
\text { L6 - L7 }\end{array}$} & \multirow{2}{*}{$\begin{array}{l}\text { Maximum } \\
\text { L6 - L7 }\end{array}$} & \multicolumn{3}{|c|}{ Ratio (as \% of carcass weight) } \\
\hline & L6 (n:5) & L7 (n:4) & Sig. & & & L6 (n: 5) & L7 (n: 4) & Sig. \\
\hline \multicolumn{9}{|c|}{$\begin{array}{l}\text { Individual cuts in the } \\
\text { carcass }\end{array}$} \\
\hline Leg & $5.942 \pm 0.079$ & $6.209 \pm 0.052$ & 0.032 & $\begin{array}{l}5.713- \\
6.073\end{array}$ & $\begin{array}{l}6.095- \\
6.321\end{array}$ & $30.187 \pm 0.621$ & $31.636 \pm 0.658$ & 0.156 \\
\hline Foreleg & $3.537 \pm 0.191$ & $3.349 \pm 0.141$ & 0.475 & $\begin{array}{l}3.048- \\
3.057\end{array}$ & $\begin{array}{l}4.229- \\
3.646\end{array}$ & $17.950 \pm 0.923$ & $17.034 \pm 0.552$ & 0.453 \\
\hline Back & $1.673 \pm 0.111$ & $1.565 \pm 0.061$ & 0.453 & $\begin{array}{l}1.272- \\
1.422\end{array}$ & $\begin{array}{l}1.882- \\
1.713\end{array}$ & $8.502 \pm 0.597$ & $7.991 \pm 0.459$ & 0.537 \\
\hline Loin & $1.560 \pm 0.096$ & $1.849 \pm 0.060$ & 0.048 & $\begin{array}{l}1.345- \\
1.712\end{array}$ & $\begin{array}{l}1.851- \\
2.000\end{array}$ & $7.967 \pm 0.653$ & $9.435 \pm 0.470$ & 0.127 \\
\hline Neck & $3.031 \pm 0.266$ & $3.085 \pm 0.212$ & 0.883 & $\begin{array}{l}2.512- \\
2.711\end{array}$ & $\begin{array}{l}4.044- \\
3.695\end{array}$ & $15.392 \pm 1.378$ & $15.668 \pm 0.806$ & 0.877 \\
\hline Breast+flank & $2.664 \pm 0.310$ & $2.404 \pm 0.165$ & 0.516 & $\begin{array}{l}2.095- \\
2.123\end{array}$ & $\begin{array}{l}3.860- \\
2.834\end{array}$ & $13.404 \pm 1.186$ & $12.210 \pm 0.641$ & 0.440 \\
\hline Tail & $0.848 \pm 0.154$ & $0.813 \pm 0.128$ & 0.869 & $\begin{array}{l}0.570- \\
0.480\end{array}$ & $\begin{array}{l}1.340- \\
1.075\end{array}$ & $4.248 \pm 0.677$ & $4.120 \pm 0.622$ & 0.896 \\
\hline $\begin{array}{l}\text { Perinefral } \\
\text { and pelvic } \\
\text { fat }\end{array}$ & $0.465 \pm 0.037$ & $0.376 \pm 0.036$ & 0.133 & $\begin{array}{l}0.380- \\
0.315\end{array}$ & $\begin{array}{l}0.560- \\
0.480\end{array}$ & $2.350 \pm 0.145$ & $1.906 \pm 0.140$ & 0.068 \\
\hline \multicolumn{9}{|l|}{ Category } \\
\hline First quality & $9.175 \pm 0.226$ & $9.623 \pm 0.102$ & 0.144 & $\begin{array}{l}8.331- \\
9.332\end{array}$ & $\begin{array}{l}9.560- \\
9.786\end{array}$ & $46.656 \pm 1.714$ & $49.062 \pm 1.481$ & 0.338 \\
\hline $\begin{array}{l}\text { Second } \\
\text { quality }\end{array}$ & $3.537 \pm 0.191$ & $3.349 \pm 0.141$ & 0.475 & $\begin{array}{l}3.048- \\
3.057\end{array}$ & $\begin{array}{l}4.229- \\
3.646\end{array}$ & $17.950 \pm 0.923$ & $17.034 \pm 0.552$ & 0.453 \\
\hline Third quality & $5.695 \pm 0.359$ & $5.490 \pm 0.367$ & 0.704 & $\begin{array}{l}4.872- \\
4.881\end{array}$ & $\begin{array}{l}6.873- \\
6.528\end{array}$ & $28.796 \pm 1.204$ & $27.878 \pm 1.378$ & 0.630 \\
\hline \multicolumn{9}{|c|}{ Composition of the carcass } \\
\hline Lean & $9.984 \pm 0.186$ & $10.132 \pm 0.227$ & 0.627 & $\begin{array}{l}9.466- \\
9.666\end{array}$ & $\begin{array}{l}10.553- \\
10.640\end{array}$ & $50.707 \pm 1.024$ & $51.669 \pm 1.983$ & 0.660 \\
\hline Bone & $3.388 \pm 0.112$ & $3.423 \pm 0.140$ & 0.849 & $\begin{array}{l}3.128- \\
3.076\end{array}$ & $\begin{array}{l}3.756- \\
3.759\end{array}$ & $17.264 \pm 0.895$ & $17.477 \pm 0.994$ & 0.878 \\
\hline Fat & $3.529 \pm 0.391$ & $3.140 \pm 0.333$ & 0.488 & $\begin{array}{l}2.845- \\
2.458\end{array}$ & $\begin{array}{l}5.025- \\
3.970\end{array}$ & $17.752 \pm 1.454$ & $15.906 \pm 1.382$ & 0.397 \\
\hline Remainder & $1.505 \pm 0.064$ & $1.766 \pm 0.252$ & 0.299 & $\begin{array}{l}1.333- \\
1.372\end{array}$ & $\begin{array}{l}1.634- \\
2.496\end{array}$ & $7.679 \pm 0.488$ & $8.921 \pm 1.064$ & 0.290 \\
\hline
\end{tabular}

L6 and L7: No. of lumbar vertebrae

Table 5 Means $( \pm S E)$, minimum-maximum values and ratios $( \pm S E)$ for composition of individual cuts of carcasses 


\begin{tabular}{|c|c|c|c|c|c|c|c|c|}
\hline \multirow[t]{2}{*}{ Trait } & \multicolumn{3}{|l|}{ Means (kg) } & \multirow{2}{*}{$\begin{array}{l}\text { Minimum } \\
\text { L6 - L7 }\end{array}$} & \multirow{2}{*}{$\begin{array}{l}\text { Maximum } \\
\text { L6 - L7 }\end{array}$} & \multicolumn{3}{|c|}{ Ratio (as \% of individual cuts) } \\
\hline & L6 (n:5) & L7 (n:4) & Sig. & & & L6 (n: 5) & L7 (n: 4) & Sig. \\
\hline \multicolumn{9}{|l|}{ Leg } \\
\hline Lean & $3.500 \pm 0.051$ & $3.691 \pm 0.119$ & 0.153 & $\begin{array}{l}3.334- \\
3.464\end{array}$ & $\begin{array}{l}3.601- \\
3.994\end{array}$ & $58.955 \pm 1.319$ & $59.451 \pm 1.835$ & 0.828 \\
\hline Bone & $1.087 \pm 0.033$ & $1.160 \pm 0.035$ & 0.174 & $\begin{array}{l}1.022- \\
1.067\end{array}$ & $\begin{array}{l}1.216- \\
1.232\end{array}$ & $18.294 \pm 0.526$ & $18.673 \pm 0.443$ & 0.611 \\
\hline Fat & $0.941 \pm 0.105$ & $0.935 \pm 0.093$ & 0.968 & $\begin{array}{l}0.584- \\
0.701\end{array}$ & $\begin{array}{l}1.136- \\
1.141\end{array}$ & $15.754 \pm 1.591$ & $15.070 \pm 1.532$ & 0.770 \\
\hline Remainder & $0.415 \pm 0.035$ & $0.423 \pm 0.026$ & 0.858 & $\begin{array}{l}0.281- \\
0.349\end{array}$ & $\begin{array}{l}0.478- \\
0.466\end{array}$ & $6.997 \pm 0.647$ & $6.806 \pm 0.371$ & 0.819 \\
\hline \multicolumn{9}{|l|}{ Foreleg } \\
\hline Lean & $2.065 \pm 0.132$ & $2.014 \pm 0.035$ & 0.746 & $\begin{array}{l}1.736- \\
1.951\end{array}$ & $\begin{array}{l}2.537- \\
2.093\end{array}$ & $58.289 \pm 0.808$ & $60.338 \pm 1.647$ & 0.270 \\
\hline Bone & $0.719 \pm 0.055$ & $0.655 \pm 0.031$ & 0.379 & $\begin{array}{l}0.599- \\
0.569\end{array}$ & $\begin{array}{l}0.886- \\
0.718\end{array}$ & $20.385 \pm 1.389$ & $19.558 \pm 0.478$ & 0.627 \\
\hline Fat & $0.431 \pm 0.067$ & $0.404 \pm 0.054$ & 0.772 & $\begin{array}{l}0.268- \\
0.283\end{array}$ & $\begin{array}{l}0.613- \\
0.527\end{array}$ & $12.125 \pm 1.632$ & $11.938 \pm 1.178$ & 0.932 \\
\hline Remainder & $0.322 \pm 0.027$ & $0.276 \pm 0.036$ & 0.334 & $\begin{array}{l}0.251- \\
0.180\end{array}$ & $\begin{array}{l}0.396- \\
0.348\end{array}$ & $9.200 \pm 0.882$ & $8.167 \pm 0.791$ & 0.424 \\
\hline \multicolumn{9}{|l|}{ Back } \\
\hline Lean & $0.787 \pm 0.024$ & $0.780 \pm 0.029$ & 0.847 & $\begin{array}{l}0.703- \\
0.724\end{array}$ & $\begin{array}{l}0.847- \\
0.851\end{array}$ & $47.651 \pm 2.350$ & $49.875 \pm 0.980$ & 0.453 \\
\hline Bone & $0.377 \pm 0.054$ & $0.339 \pm 0.050$ & 0.626 & $\begin{array}{l}0.264- \\
0.240\end{array}$ & $\begin{array}{l}0.519- \\
0.431\end{array}$ & $22.415 \pm 2.469$ & $21.404 \pm 2.451$ & 0.783 \\
\hline Fat & $0.407 \pm 0.072$ & $0.333 \pm 0.026$ & 0.413 & $\begin{array}{l}0.220- \\
0.274\end{array}$ & $\begin{array}{l}0.659- \\
0.390\end{array}$ & $23.774 \pm 3.112$ & $21.500 \pm 2.268$ & 0.592 \\
\hline Remainder & $0.102 \pm 0.014$ & $0.113 \pm 0.015$ & 0.614 & $\begin{array}{l}0.071- \\
0.080\end{array}$ & $\begin{array}{l}0.153- \\
0.148\end{array}$ & $6.160 \pm 0.726$ & $7.221 \pm 0.884$ & 0.380 \\
\hline \multicolumn{9}{|l|}{ Loin } \\
\hline Lean & $0.875 \pm 0.059$ & $1.058 \pm 0.032$ & 0.040 & $\begin{array}{l}0.684- \\
0.995\end{array}$ & $\begin{array}{l}1.037- \\
1.118\end{array}$ & $56.219 \pm 2.631$ & $57.328 \pm 1.806$ & 0.752 \\
\hline Bone & $0.235 \pm 0.041$ & $0.289 \pm 0.029$ & 0.344 & $\begin{array}{l}0.128- \\
0.210\end{array}$ & $\begin{array}{l}0.325- \\
0.343\end{array}$ & $14.722 \pm 1.906$ & $15.557 \pm 1.258$ & 0.741 \\
\hline Fat & $0.328 \pm 0.047$ & $0.371 \pm 0.037$ & 0.516 & $\begin{array}{l}0.226- \\
0.264\end{array}$ & $\begin{array}{l}0.505- \\
0.431\end{array}$ & $21.367 \pm 3.632$ & $20.067 \pm 2.004$ & 0.780 \\
\hline Remainder & $0.122 \pm 0.019$ & $0.131 \pm 0.017$ & 0.734 & $\begin{array}{l}0.073- \\
0.080\end{array}$ & $\begin{array}{l}0.167- \\
0.152\end{array}$ & $7.693 \pm 0.867$ & $7.048 \pm 0.828$ & 0.614 \\
\hline \multicolumn{9}{|l|}{ Neck } \\
\hline Lean & $1.511 \pm 0.044$ & $1.534 \pm 0.059$ & 0.760 & $\begin{array}{l}1.383- \\
1.398\end{array}$ & $\begin{array}{l}1.625- \\
1.670\end{array}$ & $51.225 \pm 4.134$ & $50.341 \pm 3.558$ & 0.880 \\
\hline Bone & $0.602 \pm 0.023$ & $0.615 \pm 0.065$ & 0.840 & $\begin{array}{l}0.543- \\
0.441\end{array}$ & $\begin{array}{l}0.645- \\
0.722\end{array}$ & $20.526 \pm 1.992$ & $20.472 \pm 2.896$ & 0.988 \\
\hline Fat & $0.633 \pm 0.290$ & $0.311 \pm 0.028$ & 0.362 & $\begin{array}{l}0.211- \\
0.242\end{array}$ & $\begin{array}{l}1.771- \\
0.370\end{array}$ & $18.632 \pm 6.505$ & $10.103 \pm 0.691$ & 0.287 \\
\hline Remainder & $0.286 \pm 0.018$ & $0.625 \pm 0.260$ & 0.181 & $0.224-$ & $0.331-$ & $9.617 \pm 0.818$ & $19.085 \pm 6.364$ & 0.139 \\
\hline
\end{tabular}




\begin{tabular}{|c|c|c|c|c|c|c|c|c|}
\hline \multicolumn{9}{|c|}{ Breast+flank } \\
\hline Lean & $1.246 \pm 0.078$ & $1.055 \pm 0.049$ & 0.094 & $\begin{array}{l}1.098- \\
0.953\end{array}$ & $\begin{array}{l}1.536- \\
1.189\end{array}$ & $47.829 \pm .638$ & $44.267 \pm 2.581$ & 0.374 \\
\hline Bone & $0.368 \pm 0.029$ & $0.366 \pm 0.045$ & 0.961 & $\begin{array}{l}0.320- \\
0.307\end{array}$ & $\begin{array}{l}0.455- \\
0.498\end{array}$ & $14.139 \pm 1.032$ & $15.252 \pm 1.650$ & 0.569 \\
\hline Fat & $0.791 \pm 0.249$ & $0.787 \pm 0.155$ & 0.991 & $\begin{array}{l}0.339- \\
0.554\end{array}$ & $\begin{array}{l}1.732- \\
1.232\end{array}$ & $27.434 \pm 5.140$ & $32.188 \pm 4.460$ & 0.520 \\
\hline Remainder & $0.259 \pm 0.038$ & $0.197 \pm 0.018$ & 0.219 & $\begin{array}{l}0.138- \\
0.148\end{array}$ & $\begin{array}{l}0.366- \\
0.236\end{array}$ & $10.597 \pm 2.115$ & $8.293 \pm 0.983$ & 0.396 \\
\hline
\end{tabular}

L6 and L7: No. of lumbar vertebrae

\section{Figures}

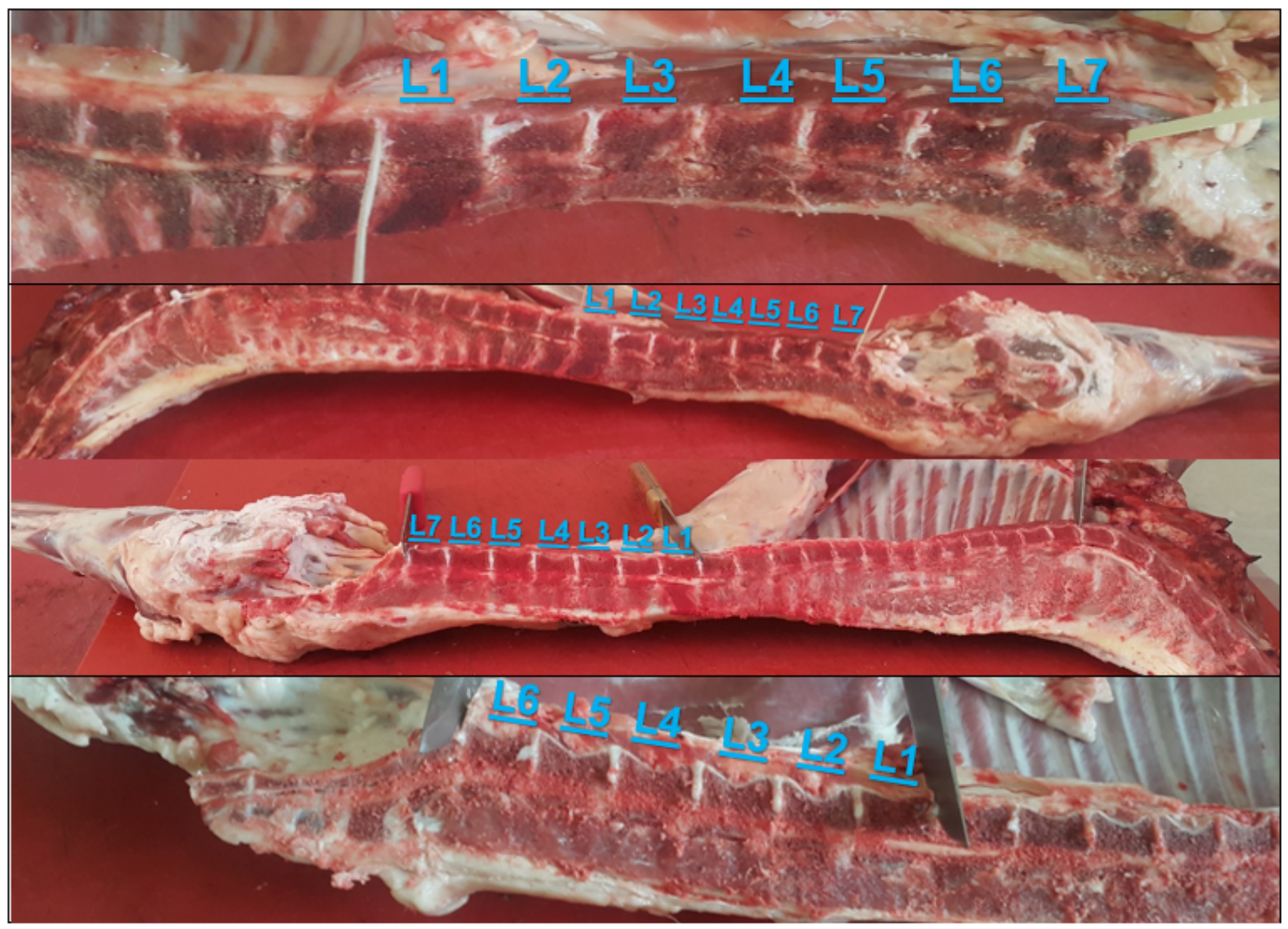

\section{Figure 1}

Some carcass photos for the carcasses having 6 and 7 lumbar vertebrae 


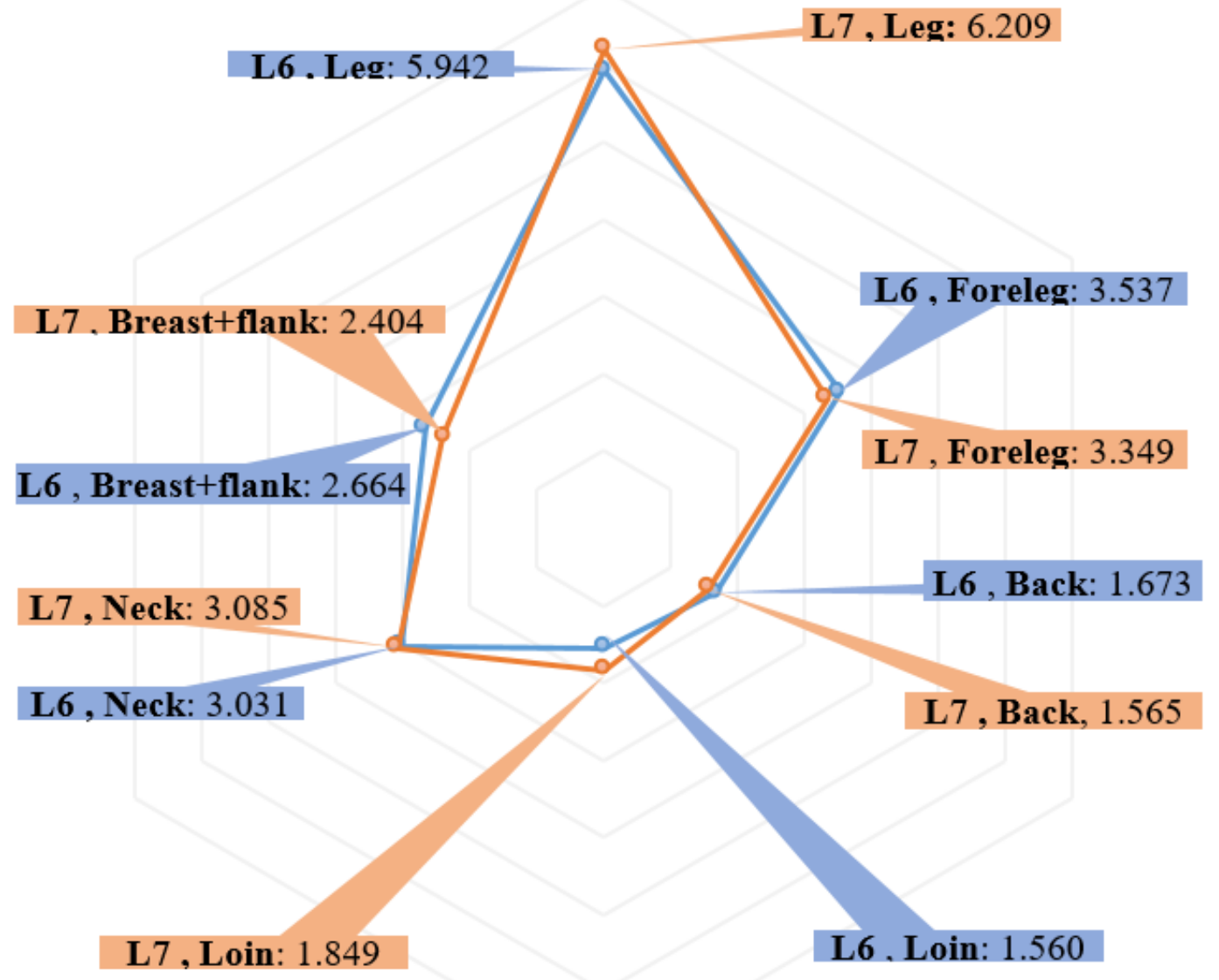

Figure 2

Means for individual cuts in the carcass $(\mathrm{kg})$ 


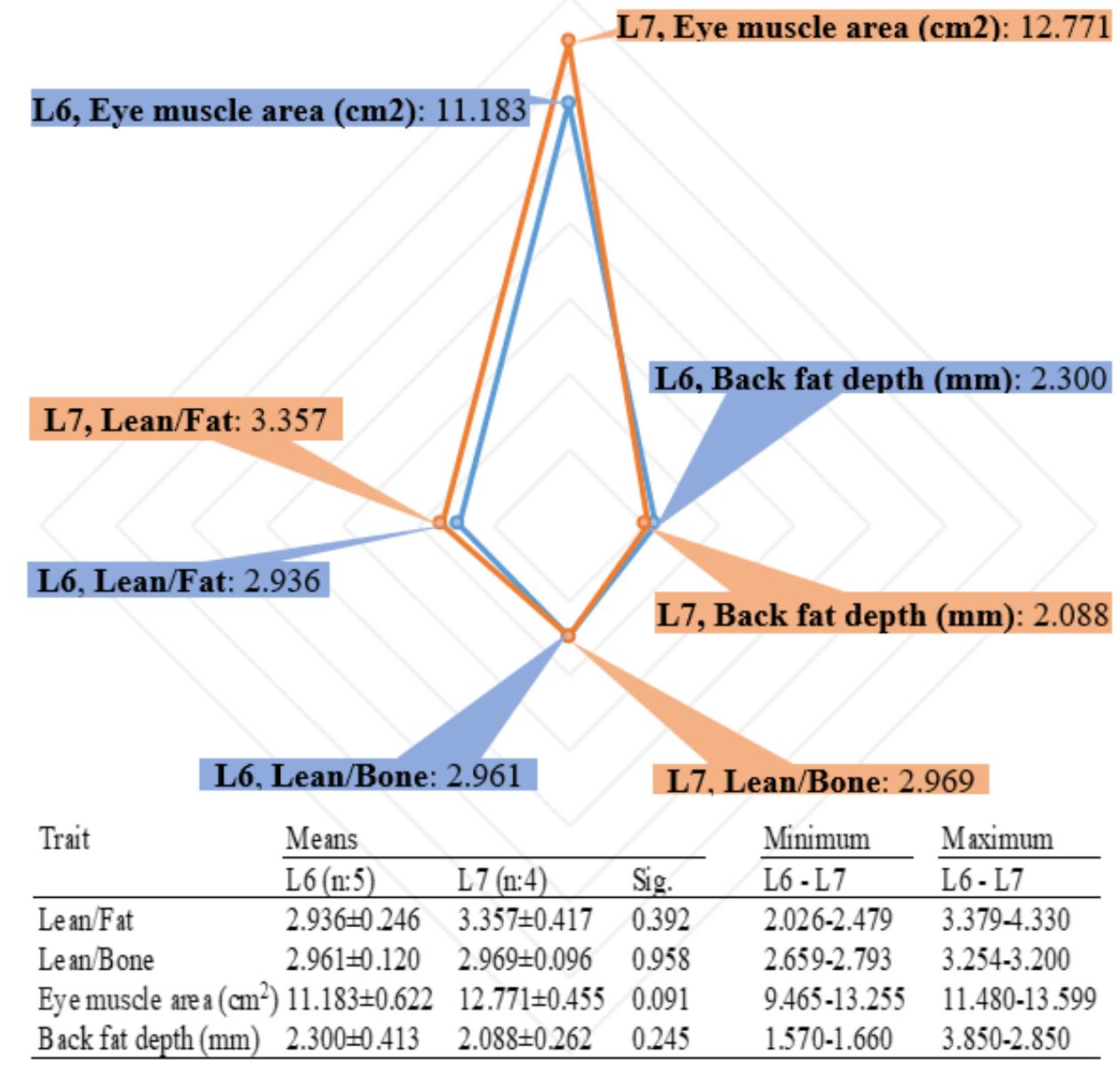

Figure 3

Means $( \pm S E)$ and minimum-maximum values for some carcass traits 


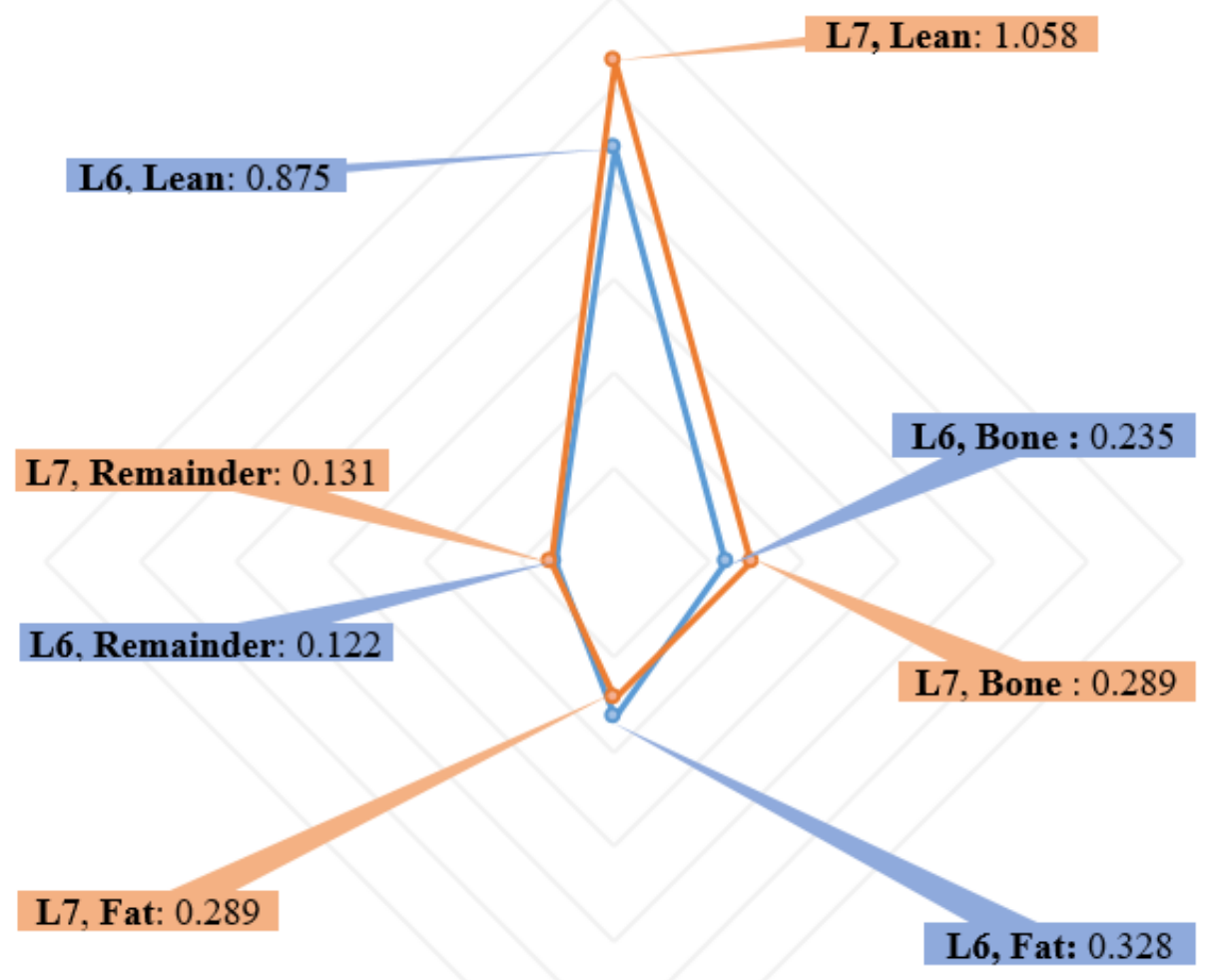

Figure 4

Means for composition of the loin $(\mathrm{kg})$ 